\title{
Assessing Earthquake Risks along the West African Coast in the Present Climate Change Setting
}

\author{
ArinzeTagbo Mozie ${ }^{1}$, Ayadiuno, R. U. ${ }^{2}$, Onyekwelu, C. A. ${ }^{3}$ and Upa, C., \\ ${ }^{4}$ Okafor P. U \\ ${ }^{1,2,3,4}$ (M,Sc Geomorphology)Lecturer,Department of Geography, University of Nigeria Nsukka.
}

\begin{abstract}
The author contends using documented evidence from earlier climate change episodes, that the present climate change episode will also result in crustal movements and adjustmentsand not only in climaterelated hazards as is being recently experienced. The author relies on facts about thetheories of earth structures and systems theory.The author points out recent earthquakes in places that were hitherto not known to be earthquake prone, presents evidence of past and recent tectonic activities in Africa, West Africa and Nigeria and argues that earthquakes risks being matters of probability can occur anywhere on earth under the Law of Averages or as is called in this paper, the Law of Similar Antecedents. The paper ends with a call on the governments of West African countries to commence preparations against earthquake risks as in the advanced countries of the world.
\end{abstract}

Key words: Earth, Quakes, Risk, West Africa, Assessment, Tectonics.

\section{Introduction}

Climate sustains life on earth. (Ojo, Ojo and Oni,2001). Climate is defined in this paper to mean "the state of the atmospheric system at a place over a specified long period of time and its effects on biosphere". The sub-parts of the atmospheric system interact at various intensities and in specific patterns at given times to produce the seasonal cycles noticed via certain events, certain states of the atmospheric systems and certain types of human activities.Climate change is defined in this paper as a change in the state of the earth's atmospheric system over a sufficiently long period of time, which in turn is a result of changes in the dynamics of interactions in the earth's atmospheric system, including alterations in the sequence of events in the atmospheric cycles, changes in the character of the cycles themselves and changes in the effects of the atmospheric cycles experienced as departures from what was hitherto thought to be normal by human beings. Climate change is not new to the earth (www.wikipedia. org, 2009).Before the present climate change, climate change was understood to be cyclical in occurrence (Velikovsky 1950; Flint 1957). Thornbury (1954) credited the understanding of the cyclical nature of climate change via the alternating glacial and inter-glacial epochs to the works of Agassiz, de Sassaure, Penck and Bruckner amongst others in the cool temperate latitudes.Penck went on to assert that the earth's atmosphere was a system and that the climate changes in the temperate regions had correlated changes in other parts of the world ( Ofomata 2001).

The present change in the earth's climate is driven by global warmingdue to greenhouse effect (IPCC 2001, 2004; Ajaero, Akukwe and Asuoha 2009). The earth's mean temperature is now about $0.9^{\circ} \mathrm{C}$ above its 1900 value (IPCC 2001). Many pieces of evidence point to the past changes in the earth's climate and environment systems being tied to and driven by alternate global warming and cooling resulting in corresponding glacial melting and accumulation(Velikovsky, 1950). Flint (1957), Donovan and Jones (1979), Devoy (1987a) and Summerfield (2000) provided evidence that the earth's climate and environment systems had changed in the past epochs with the alternating cycles of glacial accumulations (glacials) and glacial meltings (inter glacials). Glacial epochs in the temperate and polar region coincide withtropical interpluvials, while the interglacial epochs in the temperate and polar regions coincide with pluvial periods in the humid tropics (Ewing and Donn 1956; Sahagian 1987; Summerfeild, 2000). A warmer earth caused by an abnormal level of greenhouse gases in her atmosphere, leads to higher mean global temperatures, global warming, the melting of the polar glaciers, higher evaporation rates and levels, prolonged and heavy rain falls, floods, greater ground loss, stream sedimentation, more water in the ocean basins, sea floor sagging, sea level rise and a redistribution of the crustal and lithospheric materials on the aesthenosphere which is accommodated in such a manner that the earth retains its peculiar geoidal and ellipsoidalshapeto assure the smallest friction between the earth and stellar matter through which it moves(Wooldridge and Morgan 1959). The effect of climate change touches on every aspect of life on earth. (Hadley Center 1995, IPCC 2007, ClimAfrica,2011).

Recent climate change has been blamed on a crowded earth in which human activities have forced and accelerated changes in the composition of the atmospheric gases, the earth's heat balance and 
therelationshipsbetween the climate variables (Schware and Kellog 1983; IPCC 2001). Recorded and advertised climate-related disasters give the impression that climate change will only result in floods, droughts, extremes temperatures, sea level changes, re-emergence of certain diseases, shifts in lines of diseases occurrences, loss of biodiversity etc.(See IPCC 2007, ClimAfrica 2011). This is not exactly true as hazards outside the atmospheric realm may also occurand as they had occurred in the past periods of climate change (Schware and Kellog 1983).

\section{The Goal And Contention Of This Paper}

Because of the general belief that only atmospheric disasters will accompany climate change, the goal and contention of this paper is to present credible documented evidence that climate change via global warming and glacial melting, can also result in global structural changes. The structuralchanges will result in widespread sea level changes, crustal movements thecreation of fresh faults, opening of formerly closed fractures and vents, volcanoes and earthquakes before the completion of the current regime of global climate change. It is foreseeable that by the time the present climate change plays out, the earth's surface would not be exactly as it is today.

\section{Facts for Consideration}

The constituent parts of the internal structures of the earth are now largely well-known (Summerfield 2000, Ofomata 2008). The lighter, outermost crustal and lithospheric layers rest and float upon the denser and semi- liquidsimatic (magmatic) layers. The simaticlayer which is about $100 \mathrm{~km}$ beneath the lithosphere exists under great heat and pressure (Ofomata 2008). This zone of magmatic materials is called the aesthenosphere. The temperature of the aesthenosphere is estimated to be about $4000^{\circ} \mathrm{C}$ (www.watchtower.org 2005). The aesthenosphere is able to deform in response to the pressure of the crustal layers onit in such a way that the earth retains its geoidal and ellipsoidal shapes because it is a rheid. The earth's shape has been described since Newton provide the proof in his Principiain 1687 as an oblate ellipsoid.It is because the shape of the earth is always changing due to the constant redistribution of aesthenospheric matter that surveyors assay geodetic data which enable them to make corrections for the earth's curvature after a certain number of years.Since the Principia, there have been about ten different daterminations of the ellipsoid from 1830 by Airy to the last revision of the World Geodetic System in 2004 (Torge 2001, www.wikipedia.com 2013). The flux within the aesthenosphere accounts for the geoid undulations and separations all over the earth (Torge 2001). The existence and mobility of the aesthenosphere is fundamental to the earth retaining its peculiar shape. Also, the existence of the aesthenosphere provides the basis for the proposition and viability of the Continental Drift Theory, Theory of Isostasy and Theory of Plate Tectonics (Summerfield 2000 and Ofomata 2008).

\section{The Continental DriftTheory}

The Continental Drift theory proposed the existence and subsequent serial rifting of a supercontinent of light sialic material (Pangea) which was floating on a dense simatic (aesthenospheric) layer; surrounded by a superocean (Panthalassa). The riftingsand dispersions of Pangea whose constituent parts drifted apart led to the formation of the continents and land masses and ocean basins of the world as we have them today (Ofomata 2008).

\section{Theory of Plate Tectonics}

This theory suggests that the earth's exterior consists of a system of discrete plates which are separated along boundaries (Ofomata 2008). The plates consist of the continental and lithospheric layers floating on the denser sub-lithospheric aesthenosphere. The fractured nature of the earth's outermost layer could be as aresult of the motions of the earth. The earth rotates through $111.1 \mathrm{kmsof}$ latitude every 4 minutes ie: $28 \mathrm{~km} /$ minute;revolves round the sun at $30 \mathrm{~km} / \mathrm{sec}$ for $365^{1} / 4$ days in a year and orbits within the Solar system around the hub of the Milky Way at $249 \mathrm{kms} / \mathrm{second}$ thus completing one revolution around the nebula in 310 years (www.watchtower.org 2009). The earth is always in motion.

It has been established that the earth is not a rigid body (Nelkon and Parker 1976). Thus theplates boundaries probably resulted from the multiplicity of the earth's motions and now enables the earth to absorb the stresses resulting from the motions which she undergoes. When the plates adjust (move) along their mutual boundaries, earthquakes occur. The plates are always adjusting one to the plates around it. All the shocks which result from the movements are not powerful enough to be felt at the earth's surface. They can be detected and recorded by shock detection and registration instruments called Seismographs. The plates move at rates which vary from 10-130 millimeters per year (www.watchtower.org 2002).

Most earthquakes occur along plate boundaries where $90 \%$ of major earthquakes occur (www.watchtower.org 2002). However there have been quakes which have occurred within the plates. One of such within-plate quakes occurred in 1556 in the Shanxi Province of China resulting in the deaths of 
830,000persons (www.watchtower.org 2005).Other within -plate earthquakes have also occurred in Turkestan and Siberia in recent years. (USGS Earthquakes Fact Sheet October 2011). Figure 1 illustrates the internal structure of the earth. Figure 2 shows the distribution of plate boundaries and volcanoes in the world.

\section{Theory of Isostasy}

This theory was first suggested by C. E. Dutton and suggests that the earth's plates will sink down into, or bob up from, the aesthenosphere according to their densitieslike a cork, ship or iceberg floating on water (Wooldridge and Morgan 1959; Ofomata 2008). Thus, the plates experience motion horizontally and vertically and the balance between the horizontal and vertical forces to the earth's internal magnetism and motion,account for the elevations of the features of the earth's surface and the overall shape of the earth. The earth has polar flattening measuring approximately 22 kilometersmatched by bulging at the equator. It has been suggested that the greater angular velocity of the earth along the semi-major axis (equator) is responsible for the polar flattening and the bulging at the equator (Clarke 1946, Torge 2001).

\section{Earthquakes}

Seismographers have stated very clearly that no place on earth is free from earthquakes (www.watchtower.org 2002). There are areas where earthquakes have higher probability of occurring than other areas. The general view is that there are areas of undoubted crustal stability called shields or cratons which do not experience shocks from earth movements- quakes (Summerfield 2000). But seismologists have come to state the true position that earthquakes risks are a matter of probability( USGS Factsheet 2012). It is now established that for some years since1999, earth quakes and volcanic eruption have become more frequent, more unpredictable and grater in their magnitudes.(USGS Factsheet 2012). This is why the monitoring of crustal movements should be undertaken by every government on a continuous basis so as to generate information for early warning. The argument in this paperis that within the confines of the present Climate Change (IPCC 2007) and Systems theory(Chorley 1962), asystem that is in dynamic equilibrium can have its state changed in any direction if the conditions that had earlier varied and can repeatedly vary the state of the system are present in sufficient magnitude (Howard 1965; Smalley and Vita-Finzi 1969). This Principle or Law of Averages is presented here as the Principle of Similar Antecedents and is presented as: "Where all the conditionprecedent to the occurrence of an event in a system re-occur in sufficient quantities as in the earlier cases, the event which had occurred earlier from such conditions has the highest probability of reoccurrence".It is on the basis of this rule that it is argued that if the earlier epochs of climate change witnessed crustal changes, then it is reasonable that such and similar events have very high probabilities of re-occurring under the present regime of climate change. It only remains for the phase of their occurrences to be reached. This phase is very difficult to predict given the very lengthy persistence of geologic and geomorphic structures.Tricart (1965) suggested a minimum persistence period of 100,000years for some tertiary structures. The effect of this relatively long period of persistency of geomorphic structures in respect of the average life expectancy of human beings, is to foster a sense of security and safety in societies that have not experienced hazards of such classes and magnitudes in environments thought to be safe from such hazards. This scenario is generally true in the West African region.

\section{A Warming Earth, Glacial Melting And Crustal Movements}

Donovan and Jones (1979), Devoy (1987a), Peltier (1987), Sahagian (1987), and Tooley and Shenan (1987) established the nexus between climatic oscillations in the glacial and interglacial epochs, on the one hand and crustal movements and events associated with plate adjustments such as flexures and ruptures resulting in the creation and re-opening of faults, volcanic activities, earthquakes, crustal subsidence and elevation and sea level changes on the other hand. They agreed that the earliest sea level changes occurred in the Mesozoic. Cotton (1942) identified evidence of world-wide coastal benches cut by waves in the last post-glacial epoch due to sea level rises. Some crustal uplifts of the past were found to be up to 120 meters high. Summerfeild (2000)presented pieces of evidence of crustal responses to glacial melting and sea level changes from the Mesozoic to date. The nexus between climate change and crustal movements is in the response of the earth's plates and crustal layers to pressure unloading or release. Crustal loading or pressure release results from the melting of the polar ice masses and the donation of the melt waters to the ocean basins. Geikie (1894), and Daly (1934), stated that parts of the earth sank beneath the added weight of the ice caps on them, and recovered during or after the melting of the ice cap. They stated further that the depression of the ice-laden areas resulted in the re-distribution of pressure on the aesthenosphere leading to crustal flexures or ruptures. Thus the crust moves in response to the weight on it and the response of the aesthenosphereto the weight of the crust. It was suggested that during the Würm glacial cycle, 34, 000, 000 cubic kilometers of water equivalent to an 85metre thick ice cap was extracted from the world's water cycle (Wooldridge and Morgan 1959). Thus, theformation of ice sheets involved a marked transformation of water from the liquid phase to the solid phase and the re- 
distribution of the weight on the aesthenosphere (Wooldridge and Morgan 1959). The reverse of this process is also true to the effect that any shift of weight on the aesthenosphere, amounts to the reduction of load from the earlier loaded crusts at the poles. These load alterations result in the lateral and vertical compensatory adjustments of the plates. The whole earth had been involved and affected in the isostatic adjustments of the aesthenosphere to the ice-loading and ice-melting process in the past glacial and past glacial epochs. Wooldridge and Morgan (1959) stated as follows:

"In general, it is true to say that the whole planet musttend to become adjusted isostatically to localized ice loads so that we cannot, on the theoretical grounds, set any limit of distance to the land-movement resulting from it".

It is clear that no certain limits can be set on the limit of distance to the crustal movements that will and can result when the isostatic responses commence. Following from above, no limit can be reasonably set for the isostatic responses of the plates and crustal materials. Daly (1934) and Peltier (1987) said that the eustatic oscillations of sea level and the isostatic oscillation of ice loaded tracts and associated movements were chief causes of sea level changes in the Pleistocene. Two views were held of the time frame for the sea level changes. Some scholars said it took a considerable time (Wright 1937) while some other scholars said that adjustment was immediate and affected the whole earth (Daly 1934). The idea of suddenness or slowness of the happening of environment- changing events had been argued by the Catastrophists under Cuvier and the Uniformitarianists under Lyell, laid to rest in Neo-Catastrophism now better accommodated under Gradualism which explicitly accepts the continuity in the evolution of phenomena over time.Gradualism accomdates the concepts of dynamic equilibrium and quasi- equilibrium in systems theory (von Bertalanffy 1951).If we place the contention as to the time span for the manifestation of changes on the earth's surface within systems theory and the doctrine of equifinality, we will certainly reach a conclusion that what matters isthe outcome of the process of crustal adjustments and mankind being ready for the outcomes.

What must concern mankind in this period of changes is for him to keep vigil on the earth's environment and develop response plans. Observations on the Arctic and Antarctic ice caps show that the Arctic ice cap in 1932 measured 400km in an East-West direction and 800km in the North-South direction with a mean thickness of 1500 meters indicating a considerable basal entrenchment of the glacial mass far below the surface (Wooldridge and Morgan 1959). This Arctic ice cap has been decreasing in size since the last (Quartenary) ice period (www.watchtower.org 2006). With respect to the Greenland ice sheet, the mass has decreased from an area of $1,800,000 \mathrm{~km}^{2}$ in the mid 1970 s (Holmes 1975) to about $1,450,000 \mathrm{~km}^{2}$ and from $220 \mathrm{~km}^{2}$ to $90 \mathrm{~km}^{3}$ between 2001-2006 with aflow velocity that was less than 1.0meter/yr ${ }^{-1}$ between 1930 and 1950increasing to a velocity of $12 \mathrm{~km} / \mathrm{yr}^{-1}$ in 2004-5 (Shepherd and Wingham, 2007). The ice melts have made the normally ice bound Arctic Ocean to be ice free in recent summers enabling ships to navigate through the North Pole leading to a cut in sailing expense of $\$ 450,000$ (equivalent of $€ 300,000$ and N68 million per ship per passage) by cutting the voyage short by 3,000 nautical milesand ten days of sailing time (www.watchtower.org 2010, www.voa.com 2010).

At the Antarctic, Schware and Kellogg (1983) predicted that the Antarctic glacier would break - up in a 200 year period from 1983 due to global warming and the reduction of the ozone layer over the region. This is an abrupt break-up in terms of geologic time. When the glacial melting is completed, the Antarctic ice sheet with a mean elevation of 1800 meters above sea level and a base more than 500 meters beneath the sea level and entrenched in the submerged rocks beneath, would rise. The IPCC (2007) relying on satellite imageries, reported rifts in the western Antarctic ice sheet indicating imminent breakup of the Antarctic ice sheet. A complete melting of the ice sheets will result in large scale adjustments of the ocean basins to accommodate a risen Antarctica and the large mass of water that will be released into the ocean basins. The African plate has a boundary with the Antarctic,Indian and the American plates.How much vertical uplift the Arctic and Antarctic plates will experience cannot be easily estimated. An intelligent guess can be made if it is considered that the surface of Antarctica may rise to about 400-500 meters at the end of glacial melting. This compensatory rise would result in a northward adjustment of the Antarctic plate. Given the sizes of the polar ice masses, a greater south to north adjustment is expected as against a north to south adjustment. It is the contention in this paper that the adjustments have started manifesting with the reopening of volcanic vents and the resumption of volcanic activities in areas that have been dormant over long periods. There have been incidences of sea level changes along many coastlines of the world. There have also been recent earthquakes in areas which hitherto were thought to be earthquake free. There have been more devastating earthquakes in various parts of the world. There are pieces of evidence of the extension of existing faults. These events are discussed below

\section{Recent Volcanic Activities}

In 2010, the Eyjafyallajökul volcano in Iceland which had been dormant resumed activity,spewing ash into the atmosphere which halted air traffic for days at great 
loss to European airlines. Mt.Merapi in Malaysia, a volcano which had been dormant for more than fifty years resumed activity in November 2010 without any warning (www.thenationonlineng.net 2010). Mount Etna on the island of Sicily which had been described as an effusive volcano is now described by the Italian National Geophysical and Volcanology Institute in Catania as "a volcano whose activity has become decidedly more intense making its activity more difficult to predict" (www.watchtower.org.2005). On January 28, $2011 \mathrm{Mt}$. Kirishima in Japan which was believed to be dormant, erupted spewing smoke and the volcanologists in the arearemarked that no volcano can be said to have become extinct. "You can never say never with a volcano" (The Nation 2011). A remote volcano in Aden resumed activity in late 2010 (The Nation 2010). In the Congo basin Mt Nyiragongo continues to issue its plume of smoke while Lake Nyos on Mt. Cameroun continues to indicate that things are not all calm beneath the mountain chain. It needs be said that the Mt. Cameroun orogeny affected most of Sotheastern Nigeria including the uplifting, tilting and rifting of theNsukka- Ud-Awgu- Okigwe Cuesta.

\section{Faults And Earthquakes}

Faults provide the sites for earthquakes and volcanic eruptions (Christopherson 2006). Faults are created by tensional and compressional forces which rupture the earth's crust (Ofomata, 2008). The Mexican volcano El Paricutin arose without any warning through a fault in a cornfield in 1943 (Trewartha1974).Faults occur, close, re-occur and or extend according to the tensional and compressional forces operating in the aesthenosphere, the magnitude and pattern of the tension and pressure distribution therein which stretch or compress the crust lying on the aeshenosphere. In recent times, there have been earthquakes in Britain in 2010; Malawi in 2010; Kenya in 2010; Tanzania in 2010 and in New Zealand in 2010. Earth quakes have continued in greater frequencies and magnitudes up till the last event in China (www.alJazeera.com 2013). The tsunami of December 2004 to January 2005 resulting from a massive sub marine quake in the Pacific basin which claimed more than 175, 000 lives has never occurred in such a wide expanse of territory in human history (www.fedralradiocorporation.ng.net2009).The Fukushima earthquake in Japan is a landmark event of its own. On August 23, 2011, a 6.3 magnitude earthquake occurred in the state of Virginia in the United States of America (The Nation 2011) and on the $24^{\text {rd }}$ of October 2011 a 7.2 magnitude occurred in Turkey. The quakes and volcanic eruptions are still continuing (www.wikipedia .com 2013).

\section{Africa's Case}

The African continent, the core region of ancient Gondwanaland is described in all texts as stable (Wooldridge and Morgan 1959; Bartholomew 1974; Faniran and Jeje 1983 and Summerfield 2000). This description excludes North and Northwest Africa including Algeria, Morocco and Tunisia where earthquakes have repeatedly occurred for some years, because these countries are on the boundary between the African and Eurasian plates. The common belief is that the rest of Africa is free from earthquakes. This belief has been overturned by the quakes which occurred in Malawi, Kenya and Tanzania within 2010. Yang and Chen (2010) said that 121 earthquakes have occurred in the East African Rift Valley and that some of these earthquakes were not less than 7.0 magnitude quakes. It is very common knowledge that Africa had experienced and still experiences tectonic episodes. These past events created mountains, scarps, faults and other similar features (Faniran and Jeje 1983). Mount Nyiragongo in Zaire is an active volcano. Mount Cameroun and the ranges on the eastern borderlands of Nigeria show ample evidence of volcanic activity. As a mater of fact, the entire length of the River Niger run along an ancient fault line from the Fouta Jallon to the Niger Delta. The same fact applies to the Benue Valley. A remote and dormant volcano in Eritrea resumed activity in 2010 without warning. These examples indicate that Africa though deemed to be tectonically stable is nottotally free of hazards associated with tectonism.

\section{Nigeria's Case}

There is evidence that no part of Nigeria was exempted from the tectonic activities of the past eras (Kogbe,1976). Akpati (2010) described the eastern borderlands as still being tectonically active. Akpati (2010) cited the activities in and around Lake Nyos as evidence of possible crustal movements in that region. Accra was devastated by an earthquake in 1909. This quake was followed by two more quakes in 1924 and 1942 (Akpati 2010). This author's mother had related that the 1942 quake in Ghana was felt in Lagos because she was living in the city at the material time (Mozie 1988). In 1981, Lake Nyos released carbon monoxide that wiped out all life on its shore. This is a clear sign that there is activity within the mountain chain. It is an active zone of tectonism. Akpati (2010) said that in August 1988, the loud booming sound from within the earth which was heard in and around Ijebu Ode was a crustal movement. He observed that a fault line had extended and is still extending laterally from the Mid Atlantic ridge and fault system towards the West African coast. It is this author's supposition that this fault is extending generally towards the continental platform in the Bightof Benin 
due to the combined effects of shoreline sagging, sea level rise and oil exploration and related activities using high explosives which disturb the crustal materials (Awosika 2008, Akpati 2010 and Adeleye 2011).

The Ijebu Ode episode of 1988 may probably be the harbinger of crustal movements in South western Nigeria. There is now clear cut evidence that the sea is encroaching on the coastlines of Nigeria and coastal communities are endangered (Ndikanwu 2011). The issue is that whether it is the crust that is sagging due to increased water pressure on the sea floor or the ocean that is increasing in volume due to thermal expansionor a combination of both processes. There is the need to re-asses the situation honestly.

Are We Prepared?This question is adopted from the editorial advertised by The Nation Newspaper (www.thenationonline.ng 2010) because it is followed up by a most apposite statement which runs thus "Disaster in other places are a wake - up call for us to do the needful".Further comments state that even though Nigeria and West Africa largely cannot be said to be in natural disaster-prone area, natural disasters occur and sometimes without warning. For such reason, West Africans and their governments have to be prepared for any eventualities. The advertised editorial argued that:

"It is not enough for the Federal Government to have agencies with epithets like "assured rescue capacity" when the agencies themselves need urgent rescue intervention".

Because earthquakes have occurred in some areas in the past and stopped, new fault discovered and old faults reactivated all in this period of global warming, there is good reason for the commencement of a constant monitoring of the earth's surface for unusual crustal displacements that may signal more serious events.

\section{Conclusion}

Experts have expressed the opinion that Nigeria and by extension West Africa is not free from earthquake risks (Adeleye 2010 cited in Durojaiye 2011). These opinions call for the close monitoring of the topography to identify deformations of the earth crust in areas identified as high risk zones. Okeke (2011) had suggested the use of InSAR (Synthetic Aperture Radar Interferometry) techniques for topographic mapping and earth surface deformation monitoring in Nigeria. His suggestion on the basis of InSAR is for us to produce continuous spatial coverage and provide comprehensive map of topographic deformations in the areas covered. It was Okeke's view that such a programme"is important for Nigeria because natural and man-made factors causing earth surface deformation are abundant and widespread in Nigeria and areas of risk need to be under constant surveillance." This author associates himself with the rejection of the idea that Nigeria and West Africa are earth-quake free and joins the experts to call for a monitoring of the West African space for early warning against earthquake hazards (see Durojaiye 2010) Other countries as China and Poland have done so (Durojaiye 2010). The 6.3 earthquake that shook the state ofVirginia on the eastern plains of the United State of America in the morning August $23^{\text {rd }} 2011$ is a warning that the American Plate has shifted (The Nation 2010). The BonquirilloFault moved and caused earthquake in Haiti (USGS 2010). A 7.0 magnitude earthquake rocked New Zealand on September 3, 2010 and many more quakes have continued in other parts of the world. These events give cause for concern because the African plate is a member of the global system or community of Plates. No person can predict the manner of response of the African plate to the movements of her neighbouringplates. It is sufficient that it is acknowledged in the global scientific community that the geosystems are in a state of dynamic equilibrium which state can alter if the necessary and sufficient conditions are created or come into existence. The situation calls for the adaptation and adoption of earthquake response plans and strategies now. Some West African countries like Nigeria havetheir own platforms to help in monitoring their territory. What is further needed to compliment the territorial monitoring is the establishment of seismographs; commencement of training on drills by the citizens in all parts of the West African region,with the drill procedures translated or taught in local languages. This paper is not a doomsday prediction but a call by a rational mind based on established facts for an honest plan to safeguard the people from one of the least mentioned and considered disasters which has a nexus with climate change and changes in the world's glacial regimes as it is now re-occurring today due to a progressing warming of the earth. In a system, a change in one unit often yields responses in other members of the system. The question is, "Will the African plate shift and when will it come?" There is yet no answer to this question and the best we can do is not to lapse into collective amnesia but to commence being ready even for the sake of our children. The finding of this author is that Nigerians are not prepared for any earthquake event. They keep hoping that it will not occur. This paper is a call on the Nigerian government, the governments of West African countries and African countries and their peoples to reconsider their expectations from the climate change phenomenon and widen our scope of preparations for the challenges that may occur in the future. 


\section{References}

[1]. Ajaero, C.K., T. Akukwe And G. Asuoha (2009) "Climate Change Concepts And Issues" In. Anyadike, R.N.C; Madu, I A. And Ajaero, C.K. Eds. (2009) Climate Change And The Nigerian Environment,Department Of Geography, University Of Nigeria, Nsukka. Pp. 1-17.

[2]. Akpati, B.( Professor) (2010) “One-On-One”, N.T.A Channel 8 Lagos,Programme, August, 2010, 11.00am.

[3]. Awosika, L. (2008) "Sustainable Management Of The Nigerian Coastal And Marine Environment: Important Ingredients For Achieving The Millenium Development Goals By 2015”. In: Federal. Ministry Of Environmenthousing Andurbandevelopmeent (2008)Papers Of The 1st National Environment Summit, Transcorp Hilton Hotel, Abuja, 20th-, $21^{\text {st }}$ October, 2008.

[4]. Bertalanffy, L. Von (1951) “Anoutline Of General Systems Theory,” British Journal Of The Philosophy Of Science, Vol. 1, 154165.

[5]. Cotton C.A.(1942)Climatic Accidents, Whitcombeand Tombs. Christchurch

[6]. Daly, R.A (1934)The Changing World Of The Ice Age,New Haven.

[7]. Devoy, R.J.N. (1987a) Sea Surface Studies: A Global View, London, Croon-Helm.

[8]. Donovan, D.T. And Jones, E.J.N. (1987a) "Causes Of World Wide Changes In Sea-Level”, Journal Of The Geological Society Of London, 86, 187-192

[9]. Durojaiye, B. (2010) "Nigeria Not Free From Earthquake: Expert Warns" The Nation, October 3, 2010, Lagos, Vintage Press, P.61.

[10]. Ewing, M.Anddonn, W.L. (1956)“A Theory Of The Ice Age”, Science, 106-116.

[11]. Faniran, A. Andjeje, L.K. (1983) Humid Tropical Geomorphology,Longmans, Lagos.

[12]. Flint, R.F. (1957)Glacial Andpleistocene Geology,New York, Mcgraw Hill.

[13]. Geikie, J. (1894)The Great Ice Age, Oxford University Press, London.

[14]. Hadley Climate Research Centre(1995) Climate Change File, Uk.

[15]. Inter Governmental Panel On Climate Gange (2001) Synthesis Of Working Groups Of The Ipcc.

[16]. Inter Governmental Panel On Climate Change (2007) Climate Change 2007 (4ar) Synthesis Report For Policy Makers Http:// Www. Ipcc. Ch/Pd//Assessment Report/Ar4/Syr/Ar4syr-Spmpdfsurvey For Policy Makers (Ar3) Watson, R.T. Et Al. University Press, Cambridge.

[17]. Kellogg,W.W. And Schware, R.(1983) “Society, Science And Climate Change” Dialogue,Vol. 61, March 1983, Pp. 62-69

[18]. Kogbe, C. (1976) Geology Of Nigeria, Lagos, Elizabethan Press.

[19]. Mozie, R. I. (1988) Oral Explanation On The Effect Of The 1942 Ghana Earthquake In Lagos, Ogbunike March, 1988.

[20]. Ofomata, G.E.K. (2008) General Geomorphology For Africa Enugu, Jamoe Press Ltd.

[21]. Ojo, Ojo And On1 (2001) Principles Of Dynamic Climatology, Sedec Publishers, Lagos,

[22]. Peltier, W.R. (1987) "Mechamisms Of Relative See Level Change And Geophysical Responses To Ice-Water Fooding" In: Devoy, R.J.N. E.D. (1987) Sea Surface Studies, A Global (1983)

[23]. Summerfield, M.A (2000) Global Geomorphology, New York, Mac Graw-Hill.

[24]. Tooley, M.J. And Shenan, I. (1987) Eds. "Sea Level Changes" Institute Of British Geogrphersspecial Publication, Oxford, Blackwell.

[25]. Torgey,S. (2001) Geodesy,

[26]. Trewartha, G.T. (1974)Fundamentals Of Geography,New York, Mac-Graw Hill

[27]. Tricart J. (1965) Principeset Methodes De La Geomorphologie, Masson, Paris.

[28]. The Nation (2011) Earthquake Strikes Us East Coast" Wednesday, 24 ${ }^{\text {th }}$ augst 2011. 57

[29]. United States Geological Survey (2012) Earthquake Factsheet,Www.Wikipedia.Comnovember 2011, December 2012 And May 2013.

[30]. Velikovsky, I (1950) The Worlds In Collision, New York, Pocket Books.

[31]. Wikipedia (2009) "Sea Level Rises" Accessed April 102009.

[32]. Wooldridge, S.W And R.S. Morgan (1959) An Outline Of Geomorphology: The Physical Basis Of Geography, London, Longmans

[33]. Wright, W.B. (1937) Thequatenaryice Age, London, Longman.

[34]. Www.Voa. Com (2010)" Eruption Of The Merapivolcano, "News Bulletin $4^{\text {th }}$ November $20113.00 \mathrm{am}$.

[35]. Www. Thenationonline.Ng. Net (November,2010)

[36]. Www. Thenationonline.Ng. Net (2010) "Nigeria Not Free From Earthquakes Expert Warns" $3{ }^{\text {rd }}$ October, 2010

[37]. Www. Federalradiocorporation.Ng. Net (2009)

[38]. Www. Watchtower.Org (2002) Awake: “Tapping The Earth's Energy" August 82002

[39]. Www. Watchatower.Org (2002) Awake: Earthquake Survivors Tell Their Story March 22, 2002.

[40]. Www. Watchtower.Org (2005) Awake:Naturaldisasters:Are They Getting Worse:When The Ground Convulses"July 22, 2005.

[41]. Www.Watchtower.Org(2005) Awake "A Visit To Moutours Of Fire", September 2005,

[42]. Www.Watchtower.Org (2008) Awake: Watching The World"Fossilized Rain Forest", March 2008

[43]. Www.Watchtower.Org (2010) Awake: "Earthquakes:The Deadliest Disasters" December 2010.

[44]. (Www. Watchtower. Org (2009) Awake: Earth Designed For Iife,February 2009.

[45]. Www. Watchtower. Org (2006)

[46]. Www,Aljazeera.Com ( 2013) March 152013 News Bulletin: "Earthquake N China" 


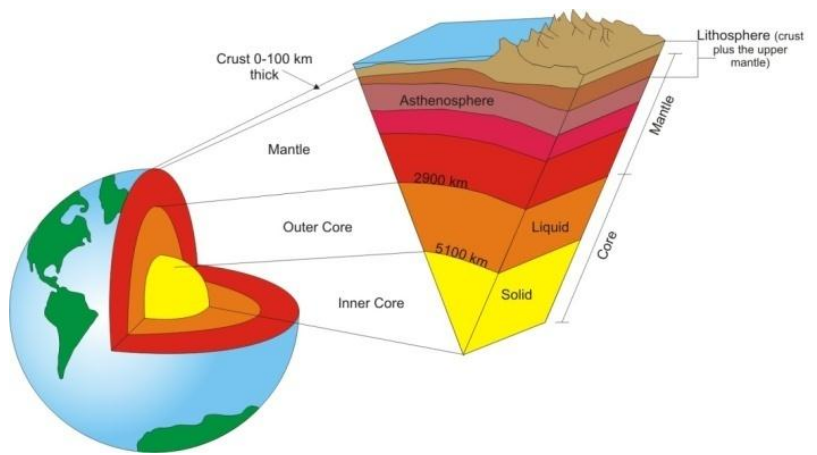

Figure 1: Internal structure of the earth

Source: Google image 2013

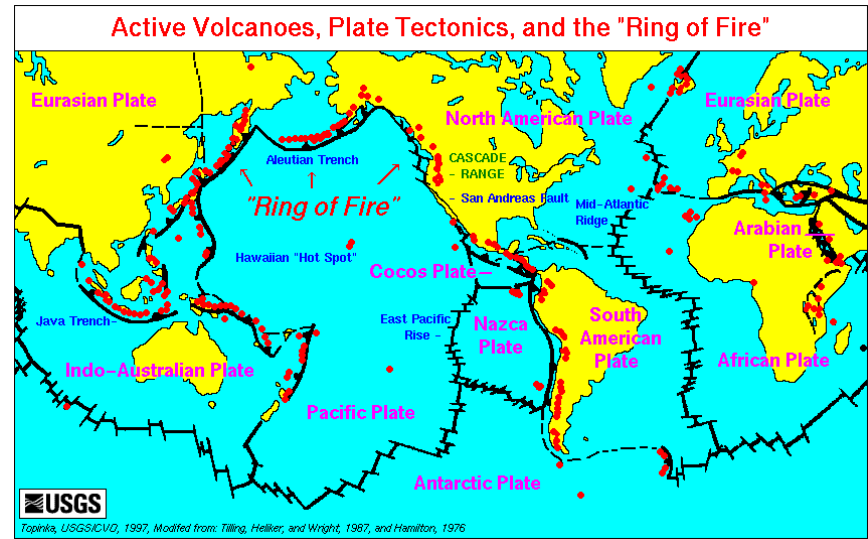

Figure 2: Active Volcanoes, Plate tectonics, "Ring of Fire" and earthquake zones of the world. 